Biesta, G.J.J. (2007). Bridging the gap between educational research and educational practice: The need for critical distance. Educational Research and Evaluation 13(3), 295-301.

\title{
Bridging the gap between educational research and educational practice: The need for critical distance
}

Gert Biesta*

University of Stirling, UK

* Institute of Education, University of Stirling, Stirling FK9 4LA Scotland, UK Email: g.biesta@ex.ac.uk

Questions about the proper relationship between educational research and educational practice have been around at least since the establishment of education as an academic field of study. In Germany this happened in 1779 when Ernst Christian Trapp became the first Professor of Education at the University of Halle. Other countries followed (much) later. England, for example had its first Professor of Education in 1873, and Scotland in 1876 (see Monroe, 1911, pp.401-409). Interestingly, Trapp gave research a central place in his conception of a science of education, although he also argued for a clear separation between educational practice and educational research and warned that teachers should not be burdened too much with the tasks of observation and experiment (see Ruprecht, 1978, p.145). The contributions to this special issue not only show that the question of the relationship between research and practice is still very much alive today. They are also testimony to the persistent nature of this question. This suggests that the issue of the relationship between research and practice may well be an endemic feature of the field of education (see, e.g., Miedema, 1986; Lagemann, 2000).

The contributions to this special issue explore a range of different aspects of the relationship between research and practice in education. All start from the assumption that there is a gap between research and practice. Some authors take a descriptive approach in that they try to outline the nature of and reasons for the alleged gap between research and practice. This is most prominent in the paper by Broekkamp and Van Hout-Wolters who provide an overview of opinions about the alleged gap between research and practice, and present different models that have been proposed for the linkage between research and practice. The latter is also the focus of the contribution by Bauer and Fischer who distinguish between three possible ways in which research and practice might interact, while De Vries and Pieters explore the role that conferences might play in the interaction between different stakeholders. Other contributions are more normative in that they try to spell out how the gap between research and practice might - or in some cases: should - be overcome. Whereas Christie and his colleagues focus on the interaction between (academic) research and educational practice, Stark and Mandl provide a model for bridging the gap between basic and applied research. Smith's contribution does not so much focus on research, but rather on the interaction between practice-based and university-based teacher educators, thus highlighting other ways in which academics and practitioners might fruitfully interact and collaborate.

Although the papers make a useful contribution to our understanding of the complexities of the relationship between academic research and educational practice, and although they provide helpful suggestions for the improvement of the interaction between research and practice, there are also some aspects that remain unexplored and there are underlying assumptions that require further scrutiny. One important issue 
Biesta, G.J.J. (2007). Bridging the gap between educational research and educational practice: The need for critical distance. Educational Research and Evaluation 13(3), 295-301.

has to do with the fact that all contributors use the word 'research' rather indiscriminately, particularly with respect to the 'outcomes' of research. They all assume that research produces knowledge and that (ideally) such knowledge should be used in educational practice and by educational practitioners. The question that is not addressed in any detail, however, concerns the different ways in which knowledge might be used and, more generally, the different ways in which educational research might be of practical relevance.

In seminal research conducted in the Netherlands in the 1980s (see, e.g., Harbers, 1986; Boon et al., 1989; see also De Vries, 1990), researchers showed that there are two distinctive ways in which educational research can inform educational practice. On the one hand research can produce 'technical' or 'instrumental' knowledge, i.e., knowledge that indicates what one should do in order to achieve a particular result or outcome. Many, if not all of the contributors in the special issue seems to assume that this is the (ideal or only) way in which research might inform practice; i.e., research should provide practitioners with knowledge about effective teaching strategies, effective assessment practices, effective strategies for supporting learning, and so on. Recent discussions about evidence-based practice and the call for the production of scientific knowledge that tells us 'what works' (see, e.g., Slavin, 2002; 2004; for a critical discussion see Biesta 2007) are all examples of the idea that if research is to be of any use for educational practice it should perform what De Vries (1990) has called a technical role. But the technical role - i.e., the provision of technical or instrumental knowledge - is only one way in which research can be useful for educational practice. The other way in which research can inform and improve practice is through the provision of different interpretations and understanding of educational practice. This concerns what De Vries refers to as the cultural role of educational research.

The distinction between the technical and the cultural role of educational research allows us to see that the provision of technical knowledge is not the only way in which research can benefit educational practice. While there is an important task for research in finding, testing and evaluating different ways of educational action (but see below), research can also have a practical impact if it helps practitioners to acquire a different understanding of their practice. To see a classroom through the lens of behavioral objectives or through the lens of legitimate peripheral participation can make a huge difference, not only in that we can see things differently but also in that we may be able to see problems where we did not see them before. As a result, we may see opportunities for action and improvement where we did not see them before. The cultural role of educational research is thus no less practical than the technical role; it is just a different way in which research can be useful for educational practice.

When we look at the alleged gap between research and practice from this angle, it becomes clear that most if not all of the concerns found in the literature reviewed by Broekkamp and Van Hout-Wolters, but also the issues raised through their questionnaire, only refer to the technical role of educational research and completely miss the cultural role. The irony is that as soon as we include the cultural role in our understanding of the practical impact of research, we can only conclude that research has had a massive impact on educational practice. If we think, for example, of the influence of constructivist ideas on classroom practice, we have to concede that educational research has dramatically changed what happens in our classrooms and 
Biesta, G.J.J. (2007). Bridging the gap between educational research and educational practice: The need for critical distance. Educational Research and Evaluation 13(3), 295-301.

schools over the past decades (which is not to suggest that these changes have all been for the better; see Biesta 2004; 2006). This reveals, therefore, that there may appear to be a gap between research and practice if we only focus on the technical role of educational research and only have technical expectations about what research should 'do' for educational practice, but that the picture is a completely different one when we think of the relationship between research and practice in terms of the cultural role of research. In order to make progress in improving the interaction between research and practice, it is therefore of the utmost importance to have a more sophisticated and nuanced understanding of academic activity, and not to use concepts like 'research' or 'enquiry' without further qualification.

This does, however, raise a different question, which is why educational research seems not have been very successful in performing its technical role, that is, in the production of technical educational knowledge, knowledge about 'what works.' Most of the contributors to this special issue seem to assume that the reason for this has to do with ineffective communication between practice and research, as a result of which research often investigates issues that are not really relevant from a practitioner's point of view. Hence the authors look for models that can improve the communication and co-ordination between research, policy and practice. This is, e.g., what Christie and his colleagues seem to try to address, although they never engage in a discussion about the specific role and status of research in the collaboration, so that it becomes difficult to see to what extent communities of enquiry are fundamentally different from other communities of collaboration. Bauer and Fischer are much more explicit about the role of research in the collaboration between researchers and practitioners, and the different models they discuss help us so see the different ways in which practitioners and researchers might improve their communication about the aims, ends and processes of research. But the point here is not only whether improved communication between research and practice could help researchers to generate knowledge that is more relevant for practice. The more fundamental question is whether educational research can actually ever produce 'technical' knowledge. ${ }^{1}$

In order to generate technical knowledge about educational processes, we must assume that there are causal links between educational activities - such as teaching, instruction, supervision, managing - and their effects or outcomes. It is, after all, only on the basis of this assumption that it becomes possible to identify effective educational strategies and procedures. ${ }^{2}$ Whereas such linkages might exist in the case of physical interaction, the important point to bear in mind is that education is not a process of physical interaction but rather a process of symbolic or symbolically mediated action. If teaching is to have any effect on learning, it is because of the fact that students interpret and try to make sense of what they are being taught. It is therefore only through processes of (mutual) interpretation that education is possible (see Biesta 1994; Biesta \& Vanderstraeten 2001). Despite attempts of many to transform education into a causal technology (often based on the idea that we only need more research in order to find and ultimately control all the factors that

\footnotetext{
${ }^{1}$ I do not have the space to address the epistemological and ontological question this raises. I refer the reader to Biesta \& Burbules 2003 and Biesta 2007 for a more detailed discussion.

${ }^{2}$ The question here is not whether it is possible to have knowledge of such processes - a question about which objectivists and relativists or, as Broekkamp and Van Hout-Wolters call them, positivists and postmodernists, have had many unfruitful debates. The question is how educational 'outcomes' are actually 'achieved.'
} 
Biesta, G.J.J. (2007). Bridging the gap between educational research and educational practice: The need for critical distance. Educational Research and Evaluation 13(3), 295-301.

determine learning), the simple fact that education is not a process of 'push and pull' - or in the language of systems theory: that education is an open and recursive system - shows that education can never be understood in a technological sense. This is not to suggest that teaching doesn't matter at all, but it is to highlight that the effects of teaching are not produced in a causal or technological manner. This is precisely what Freud had in mind when he referred to education as one of the three 'impossible professions' (the other two being politics and psycho-analysis), where we can never be sure about the outcomes of our actions and activities (see Donald, 1992, p.1). But we shouldn't lament the technological 'deficit' of education. After all, the whole point of education is that we do not simply want to condition our students' behaviour, but rather want them to learn something; we want them to make up their own minds and draw their own conclusions.

This then might help to explain why the question of the relationship between research and practice, particularly in relation to the production of technical or instrumental knowledge, is such a persistent one - although it also indicates that many practitioners and policy makers, and perhaps even educational researchers themselves, do not seem to have a very realistic view about what educational research might achieve. Given this, it is also remarkable that none of the contributors to this special issue pay attention to the particular nature of educational processes. There is also little discussion of the particular nature of the work of teachers and other educational practitioners with the exception of the contribution by Smith. She is acutely aware of the fact that teaching is not the simple application of theoretical knowledge and practical skills. She shows that teaching is full of unexpected and unique situations which require professional judgement tailored to the unique characteristics of the situation and not the mechanical application of research-based rules for action. Smith also highlights that professional judgement in educational situations not only requires professional knowledge, but also involves "values, beliefs, courage, and imagination" (Smith, this issue). Whereas the outcomes of research might play a role in professional judgement, they can only ever assist professional judgement and action but can never dictate what should be done. Educational practice consists of situations that in a sense are always new and unique. This means that education, as Trapp already knew, is an art and not a science (see Ruprecht, 1978, p.145).

This brings me to my final point. All contributors seem to assume that bridging the gap between research and practice is basically a good thing. In one respect this is, of course, true. It seems to be a huge waste of time and resources if the outcomes of educational research never reach educational practice. Educational research is, after all, never simply research on education but always in some sense also research for education. But, as is explored in most detail in the contribution by Bauer and Fischer, there are different ways in which the gap between research and practice can be bridged. And what is the 'right way' crucially depends on what one aims to achieve in bridging the gap between research and practice which, in turn, depends on how one understands the gap in the first place. The 'unidirectional script' seems appropriate if the gap is understood as a lack of information channels from research to practice. The 'loop script' seems appropriate if the gap is understood as one where research fails to address the problems of practitioners, whereas the 'highly interactive script' seems appropriate if the gap is perceived as the absence of practitioner involvement throughout all the stages of the research process. By distinguishing between the three 'scripts' Bauer and Fischer thus help us to see that there are different gaps between 
Biesta, G.J.J. (2007). Bridging the gap between educational research and educational practice: The need for critical distance. Educational Research and Evaluation 13(3), 295-301.

research and practice, and hence different strategies for bridging such gaps. But their analytical work also is helpful in highlighting two problems with attempts to bridge the gap between research and practice. The first problem becomes particularly visible in the 'loop script' where the task of research seems to be that of solving a practical problem. Whereas this might seem the ideal way in which research can be relevant for practice, it is important to bear in mind that the ways in which practitioners or policy makers present problems - and hence articulate an alleged 'research need' - may not necessarily be the best way in which the problem should be understood. Policy makers may, for example, want to know which teaching strategies can improve student exam scores. Although this may look like a clear question for research, researchers may well want to argue - and in my view should argue - that this may not be the right research question to ask and hence not the right research problem to solve. If researchers would only focus on the role of teaching in improving student achievement they might well contribute to the (erroneous) view that other factors do not matter in relation to student achievement. Such research might therefore unwittingly contribute to a culture that always ends up blaming the teacher for everything that goes wrong. Similarly - and this is a real issues raised by the contribution by Christie and his colleagues - whereas the Applied Educational Research Scheme in Scotland may have as its aim to "carry out high quality research relevant to the National Priorities in Education" (Christie, this issue), researchers also have a duty to question these priorities and thus keep a critical distance between themselves and their 'audience'.

The need for a critical distance between research and practice is also an issue in relation to the third script that Bauer and Fischer present, the 'highly interactive script'. Bauer and Fischer make a distinction between cooperative and collaborative interaction, and characterise the latter as the situation where there is "a community of members with equal rights, duties and abilities" (Bauer \& Fisher, this issue). This may lead to a situation, as they write, in which "practitioners may act as researchers" and "scientists may act as designers of educational environments" (ibid.). In my view this is an undesirable situation since it completely blurs the distinction between researchers and practitioners. It therefore not only denies the fact that practitioners and researchers bring different expertise to the collaboration. It also forgets that practitioners and researchers have different responsibilities. By collapsing the two roles - or at least by not being aware of relevant differences - there is again a danger that researchers lose their critical distance vis-à-vis educational practice. This may particularly become a problem when researchers produce insights that are troubling for practitioners and policy makers, insights that they rather would not want to hear. Yet I would argue that this is precisely a responsibility - and perhaps even a duty - of researchers. By getting too close to educational practice, they may well put themselves in a position where they can no longer be the conveyors of any 'bad' or critical news. Researchers, to put it differently, have a particular role to play in communities of enquiry and other forms of collaboration with educational practitioners. Whereas attempts to bridge gaps between research and practice are therefore generally laudable, it is also important to remain aware of differences in expertise and responsibility between the stakeholders. This, in sum, reveals that it is as important to try to bridge gaps between research and practice as it is to keep a critical distance between the two, both from the side of educational research and from the side of educational practice. 
Biesta, G.J.J. (2007). Bridging the gap between educational research and educational practice: The need for critical distance. Educational Research and Evaluation 13(3), 295-301.

\section{References}

Biesta, G.J.J. (1994). Education as Practical Intersubjectivity. Towards a criticalpragmatic understanding of education. Educational Theory, 44(3), 299-317.

Biesta, G.J.J. (2004). Against learning. Reclaiming a language for education in an age of learning. Nordisk Pedagogik 23, 70-82.

Biesta, G.J.J. (2006). Beyond learning: Democratic education for a human future. Boulder, Co.: Paradigm Publishers.

Biesta, G.J.J. (2007). Why 'what works' won't work. Evidence-based practice and the democratic deficit of educational research. Educational Theory 57(1), 1-22.

Biesta, G.J.J. \& Burbules, N.C. (2003). Pragmatism and educational research. Lanham, MD: Rowman and Littlefield.

Boon, L. et al. (1989). Disciplines, kundes en de kwaliteit van wetenschap. Onderwijskunde, gezondheidsvoorlichting en -opvoeding in internationaal perspcetief. Onderzoeksrapport RU Limburg/RU Groningen.

Donald, J. (1992). Sentimental education. Schooling, popular culture and the regulation of liberty. London/New York: Verso.

Harbers, H. (1986). Sociale wetenschappen en hun speelruimte. Groningen: WoltersNoordhoff.

Lagemann, E.C. (2000). An elusive science. The troubling history of educational research. Chicago: Chicago University Press.

Miedema, S. (1986). Kennen en handelen. Bijdragen aan het theorie-praktijk debat in de opvoedingswetenschap. Amersfoort/Leuven: Acco.

Monroe, P. (Ed)(1911). A cyclopedia of education. Volume II. New York: The Macmillan Company.

Ruprecht, H. (1978). Die erfahrungswissenschaftliche Tradition in der Erziehungswissenschaft. In H Thiersch, H. Ruprecht \& U. Herrmann (eds), Die Entwicklung der Erziehungswissenschaft (pp.109-172). München: Juventa.

Slavin, R. E. (2002). Evidence-based educational policies: Transforming educational practice and research. Educational Researcher 31(7), 15-21.

Slavin, R. E. (2004). Education research can and must address "what works" questions. Educational Researcher 33(1), 27-28.

Vanderstraeten, R. \& Biesta, G.J.J. (2001). How is education possible? Educational Philosophy and Theory, 33(1), 7-21.

Vries, G.H. de (1990). De ontwikkeling van wetenschap. Groningen: Wolters Noordhoff. 